\title{
The Anti-Bureaucratic Ghost in China's Bureaucratic Machine
}

Iza Ding ${ }^{*}$ (1) and Michael Thompson-Brusstar ${ }^{\dagger}$ (1)

\begin{abstract}
The Chinese Communist Party's (CCP) ideology, rooted in its foundational struggles, explicitly denounces "bureaucratism" (guanliaozhuyi) as an intrinsic ailment of bureaucracy. Yet while the revolutionary Party has blasted bureaucratism, its revolutionary regime has had to find a way to coexist with bureaucracy, which is a requisite for effective governance. An antibureaucratic ghost thus dwells in the machinery of China's bureaucratic state. We analyse the CCP's anti-bureaucratism through two steps. First, we perform a historical analysis of the Party's anti-bureaucratic ideology, teasing out its substance and emphasizing its roots in and departures from European Marxism and Leninism. Second, we trace both the continuity and evolution in the Party's anti-bureaucratic rhetoric, taking an interactive approach that combines close reading with computational analysis of the entire corpus of the People's Daily (1947-2020). We find striking endurance as well as subtle shifts in the substance of the CCP's anti-bureaucratic ideology. We show that bureaucratism is an umbrella term that expresses the revolutionary Party's anxiety about losing its popular legitimacy. Yet the substance of the Party's concern evolved from commandism and revisionism under Mao, to corruption and formalism during reform. The Party's ongoing critiques of bureaucratism and formalism unfold in parallel fashion with its efforts to standardize, regularize and institutionalize the state.
\end{abstract}

Keywords: China; bureaucracy; bureaucratism; formalism; ideology; revolution; the state; institution; institutionalization

An enduring feature of Leninist regimes is the fusion of the ruling political party and the bureaucratic state. Such fusion of political powers can in part be seen in the riot of terms used interchangeably to describe central authorities in China in both popular and academic discourses, including "the Chinese government," "the Chinese Communist Party (CCP)," "the Party," "the state" and "the party-state."

Paradoxically, however, any step towards building a bureaucratic "state apparatus” (guogjia jiqi 国家机器) can yield unintended consequences for a party

* University of Pittsburgh, Pittsburgh, USA. Email: yud30@pitt.edu (corresponding author).

† University of Michigan, Ann Arbor, USA. Email: mrthomp@umich.edu. 
desirous of maintaining both political control and popular legitimacy. Economic and administrative organizations and their professional managers may drift from the preferences of political leaders; fragmented decision making may lead to bureaucratic inertia and conflict; miscommunicated information and mismatched incentives may lead to over-, under-, or symbolic implementation of policies; excessive red tape may generate inefficiency; and, perhaps most worrisomely, a lack of internal restraint and external oversight may engender corruption.

As a revolutionary party whose leaders played a starring role in overthrowing the ancien régime, the CCP, since its early days, has been wary of the many ways in which bureaucracy can be misused and abused by the individuals who inhabit it - political sins summarized in the lexicon of Chinese governance with a patent pejorative: bureaucratism (guanliaozhuyi 官僚主义). Before the Party took power, "bureaucratism" was understood to be the source of China's feudal backwardness and late-imperial misery. After the Party took power, "bureaucratism" remained a dangerous disease that detaches those who contract it from the wellspring of the Party's legitimacy, the people.

This concern was not unique to the CCP. It was Lenin who decried the "essence of bureaucratism" as a condition of "privileged persons cut off from the masses and standing above the masses." The American Revolution also fathered intense scepticism about how well state bureaucracies can serve the interest of "the people." When Hamilton convinced Washington of the new republic's need to form a national bank - the forerunner of today's massive Federal Reserve bureaucracy - he faced fierce ideological opposition from Jefferson, Madison and other "founding fathers." Although political life in revolutionary regimes must eventually routinize, revolutionary fervour often lives on in one way or another as a part of the nation's identity, even decades after the revolution. ${ }^{2}$ Such fervour, regardless of its conduit, be it elite messaging or societal mobilization, cuts against the equally strong current of bureaucratization which Weber deemed an inescapable feature of modern society.

The CCP's foundational ideologies and struggles were explicitly antibureaucratic. Its leaders, who participated in the anti-monarchical revolution of 1911 and subsequent cultural reformation movements such as the May Fourth Movement (1919), envisioned a political project so transformational that it would undo all the maladies of “old society" (jiu shehui 旧社会). And nothing captured those maladies better than the term "bureaucratism," a condition attributed to the pre-revolutionary society, which was ruled by feudal, exploitative elites and their corrupt KMT progeny. As early as 1933, Mao Zedong 毛泽东 famously declared that "we must throw this extremely evil fellow, bureaucratism, into the cesspool, because no comrade likes it." 3 The Three Anti Campaign (1952), the Great Leap Forward (1958-1962) and the Cultural

3 Mao 1933. 
Revolution (1966-1976) were but the most pronounced manifestations of anti-bureaucratism.

Still, anti-bureaucratic ideology did not disappear after the end of the Mao era, even as state bureaucracies blossomed, strengthened and modernized under economic reform. All CCP leaders after Mao have continued to speak loudly and often against "bureaucratism." As recently as 2020, the Party launched a campaign to study an edited volume of Xi Jinping's 习近平 speeches and writings condemning bureaucratism, deeming it an "enemy of the Party and enemy of the people." 4 To the extent that the Party acknowledged its early mismanagement of the Covid-19 pandemic, it placed fault in "bureaucratism" among local officials. 5

When the need for a modern bureaucracy with which to govern collides with a ruling party's ideological anxiety over the ailments of bureaucratism, what kind of politics results? We contend that the outcome is a "ghost in the machine," a term Gilbert Ryle coined to critically describe Cartesian mind-body dualism. ${ }^{6}$ Like Ryle, who rejected the separation of the mind and the body - a rejection that ultimately found scientific support, we use this metaphor to describe the interdependent duality (instead of oppositional dualism) of the anti-bureaucratic "mind" within the bureaucratic "body" of Chinese politics. ${ }^{7}$ Specifically, in our case, technocratic-rational imperatives prompt the ongoing transformation of the bureaucratic apparatus, but this machine is forever haunted by the ideological impulse of an anti-bureaucratic ghost. (Informatively, "machine" is a term many scholars, from Marx to Weber, have used to refer to the bureaucratic state.)

The Party is thus perpetually pinned between the desiderata of state-building and state-breaking, of regulation and revolution, of legality and morality, and of institutional capacity and political purity. Sometimes, the ghost prevails outright; other times the machine churns unmolested; but most often this duality of bureaucratic modernization and anti-bureaucratism is never fully resolved in either direction, but instead constitutes a dynamic equilibrium.

This article considers both the persistence and transformation of this antibureaucratic ghost in the bureaucratic machine as the CCP reaches 100 years of age. It begins with a historical analysis of the CCP's anti-bureaucratic ideology, emphasizing its roots and departure from that of the Soviets. We use speeches and writings by Party leaders and the secondary literature to apprehend the Party's conceptualization of bureaucratism and its evolution over time.

Having situated "bureaucratism" historically, we then examine anti-bureaucratism over the long run by tracing elite discourse. Taking an interactive approach that combines close reading with computational analysis, ${ }^{8}$ we conduct a text analysis of all People's Daily (Renmin ribao 人民日报) articles between 1947 and 2020 and then

4 State Council Information Office 2020.

5 Tian 2020.

6 Ryle 2009[1949].

7 Dualism refers to pairs of concepts that are dichotomous and opposed, whereas duality refers to pairs of concepts that are distinct yet interdependent. See Jackson 1999.

8 Nelson 2017. 
complement this with a close reading of a stratified random sample (736 articles). We find striking endurance as well as subtle shifts in the substance of the CCP's antibureaucratic ideology. We show that bureaucratism is an umbrella term that expresses the revolutionary Party's fretfulness about losing its popular legitimacy, or, in the Party's words, becoming “detached from the people" (tuoli qunzhong 脱离群众).

Yet the substance of anti-bureaucratism varies over time. As the state transforms, new challenges emerge and the anti-bureaucratic ghost casts new shadows. Most interestingly, we find that the Party's critiques of bureaucratism have gravitated towards acute worries about “formalism" (xingshizhuyi 形式主义) in recent decades. Critiques of formalism are accompanied by a simultaneous rise in terminologies related to the "rationalization" (lixinghua 理性化), "routinization” (changguihua 常规化), “normalization" (biaozhunhua 标准化) and “standardization" (guifanhua 规范化) of rule. These parallel trends underscore the revolutionary regime's recognized need for bureaucratic capacity and rationality, ${ }^{9}$ and thus the lasting duality of bureaucratization and anti-bureaucratic ideology in Chinese politics.

\section{The Spirit of the Ghost}

Emerging out of the whirlwind collapse of the last dynasty, repeated trampling by imperialism, failed constitutional reforms, a short-lived political revolution and the disintegration of the fleeting republic, the CCP revolutionaries looked long and hard towards the West for solutions, including parliamentary reformism, before they embraced Marxism. It was initially not the substance of Marxism but the success of Lenin's October Revolution that convinced many Chinese nationalists that Marxist-Leninism could save the nation, not only from imperialism but, more importantly, from itself. ${ }^{10}$ The founders of the CCP wished to break China away from its past, a history of feudalism presided over by a "despotic bureaucracy." 11 Anti-bureaucratism thus stood at the centre of the CCP's revolutionary ideology.

While preparing for Land Reform in Jiangxi in 1930, Mao wrote his "Xunwu investigation” (Xиnwu diaocha 寻乌调查), a report expounding on the perennial exploitation of poor peasants in the region by feudal office holders. Mao described a court official in Xunwu county as a "bureaucratist" (guanliaozhuyizhe 官僚主义者), who "speaks pretty language, has good handwriting, is good-looking, and follows rules, like a Confucius." 12 Mao's early education was in Confucian classics but he claimed that he "hated Confucius from the

9 Although "rationality" is commonly treated as a form of praise in everyday discussion, it is a neutral term in the Weberian sense, as we use it here.

10 Schwartz 1951, 16-18. Schwartz writes that Chen Duxiu "had implied in all his writings that if the West had been able to exploit China, China herself was to blame" (18).

11 Schwartz 1951, 20.

12 Mao 1930. 
age of eight." 13 For Mao, Confucius represented a crumbling remnant of China's feudal-bureaucratic past, while Mao himself personified the heroic captain of a vivacious socialist future. Even though the Party has toned down Mao's contempt for Confucianism in recent years, with Party historians unearthing the many times Mao spoke favourably of Confucius, ${ }^{14}$ Mao's anti-bureaucratism continues to play a defining role in Chinese politics.

Mao was not alone among his contemporaries in his belief that bureaucratism results from the loss of revolutionary spirit. In his 1939 speech, "How to be a good communist” (Lun gongchandangyuan de xiuyang 论共产党员的修养), Liu Shaoqi 刘少奇 warned that earlier revolutionaries in Chinese history had turned into exploitative rulers after successfully taking power. ${ }^{15}$ Liu urged Party members to consciously cultivate their revolutionary spirit and avoid falling into bureaucratism and corruption after revolutionary victory. ${ }^{16}$

The CCP's ideology was, of course, inspired by Marxists, especially the Leninist interpretation of Marxism. ${ }^{17}$ Liu argued that a good communist is a good student of Marxist-Leninism. But Chinese and classical Marxist antibureaucratism also differed. ${ }^{18}$ Both saw bureaucracy as the vehicle of ruling-class domination. But European Marxists were more concerned with industrial capitalism whereas Chinese Marxists were more fixated on feudal patrimonialism. ${ }^{19}$ Russia was geographically connected to Europe and many of its revolutionary leaders, including Lenin, were physically based in Western Europe when they composed their treatises; Lenin wrote The State and Revolution in Switzerland, of all places. ${ }^{20}$

Perhaps owing to these European linkages, Lenin's inclination towards bureaucracy was more ambiguous than Mao's. Lenin both admonished and admired bureaucracy: his praise of the Russian post office as a model bureaucracy is well known. His writings railed against "anarchists" as much as against unrevolutionary and reformist "opportunists." 21 After the October Revolution and towards the end of his life, Lenin gravitated further towards a favourable view of bureaucracy. He tried to distinguish "parasitic" state-bureaucrats from technical experts, whom he lauded, and refused to tar the latter with the epithet "bureaucracy." 22 Mao, on the other hand, was far more derisive of

13 Terrill 1999, 8.

14 See, e.g., Han 2020.

15 Liu, Shaoqi 1939.

16 Ironically, Liu himself would be accused of these very sins three decades later, during the Cultural Revolution.

17 The Soviets were not alone in their critique of bureaucracy. German contemporaries like Weber and Michels also expressed their concerns with bureaucracy: Weber about its loss of spirit and unchecked power, and Michels about its oligarchic tendency.

18 Liu's 1939 speech warned about the dangers of divorcing (Marxist) theory from (Chinese) reality.

19 Capitalism as a form of industrial organization of labour was not as endemic in China as it was in Western Europe.

20 Many of Lenin's earlier polemics were directed at the "philistine" Marxists in Europe, especially "German bourgeois scholars." Lenin 1992[1918], 7.

21 Lenin 1992[1918], 106.

22 Lenin 1923. 
bureaucracy-friendly opportunists than of anti-bureaucratic anarchists. The young Mao viewed anarchism sympathetically. ${ }^{23}$ And, indeed, the elderly Mao revealed his anarchist side during the Cultural Revolution.

Ultimately, for most European Marxists, bureaucracy was a sick organizational structure, an institutional failure. ${ }^{24}$ For the Chinese communists, whose ideology was distinctly voluntarist, bureaucracy was a sick way of life, a moral failure. 25 "Bureaucracy" was the main bugbear of Marxists, whereas "bureaucratism" - a "thought [and] style" (sixiang zuofeng 思想作风) - became the epicentre of Maoist diatribes. ${ }^{26}$ European Marxists entertained all kinds of institutional reform; the CCP prioritized thought reform.

This is where the Chinese and the Soviets further diverged, and eventually split, in the first decade of the People's Republic of China (PRC). ${ }^{27}$ The Soviets promoted economic development through technical competence; Mao emphasized moral suasion and mass mobilization. The Soviets championed loyal experts; Mao preferred "reds." 28 After Krushchev's secret speech denouncing Stalin, Mao became leery of similar revisionism at home. Of particular relevance to Mao was the fading of revolutionary fervour and the re-emergence of the counter-revolutionary class within the state. Political authority devoid of revolutionary spirit was the essence of bureaucratism to Mao.

Perhaps the most extensive dissection of "bureaucratism" comes from Zhou Enlai 周恩来. His oft-cited 1963 essay, "Against bureaucratism" (Fandui guanliaozhuyi 反对官僚主义), outlines the "20 manifestations of bureaucratism," which can be further distilled into four major problems: commandism, factionalism, corruption and inefficiency. ${ }^{29}$ These subtypes would shape the Party's antibureaucratic ideology in the years to come, although different subtypes rose to the forefront of the Party's attentions in different time periods, precisely because the Party confronted different "real life" problems at different times.

First, Zhou warns that bureaucratic command can be "blind," "arbitrary" and "coercive." 30 Bureaucratic officials can be "arrogant," "grandiose" and "detached from the masses." This is the problem of bureaucratic commandism, an authoritarian style of cadres. Second, bureaucracy's "political apathy" causes it to "compete [with the Party] for power and fame." Cadres might engage in factional politics and dilute the unity of the Party. Relatedly, lower-level bureaucrats may become detached from upper-level authorities. This is the problem of

23 Schwartz 1951, 26.

24 This critique of bureaucracy echoes that of Weber and Michels.

25 Schurmann 1968, 212-13.

26 The distinction between "bureaucracy" and "bureaucratism" appeared in Lenin's works, but Mao's discussion of bureaucratism was much more extensive than Lenin's.

27 See Hearn 1978.

28 Schurmann 1968; Vogel 1970; Whyte 1973, 150-51. These distinctions are presented in relative terms. It is not to say that loyalty was not important in the Soviet Union, or that expertise was completely disregarded in China.

29 Zhou, Enlai 1963.

30 Authors' translation. 
bureaucratic factionalism. Third, bureaucracy breeds "selfishness," "embezzlement," "hedonism" and "nepotism." This is the problem of bureaucratic corruption. Fourth, bureaucrats can be "lost," "confused," "muddling through," “useless" and “feeding on the position like a corpse" (shiweisucan 尸位素餐). This is the problem of bureaucratic inefficiency, which includes inertia and formalism, both of which can hinder policy implementation.

Zhou argues that bureaucratism, at its core, "suppresses democracy and oppresses the masses” (yazhi minzhu, qiya qunzhong 压制民主, 欺压群众); the Party's self-image, however, is unabashedly democratic, from Mao calling the regime a "people's democratic dictatorship," to his contemporary counterparts putting the word democracy front and centre in the Party's "socialist core values" (shehuizhuyi hexin jiazhiguan 社会主义核心价值观). ${ }^{31}$ To be sure, the CCP's conception of democracy is not Schumpeterian or parliamentarian: under Mao, it called for mass participation; after Mao, it called for policy responsiveness. ${ }^{32}$ But this concern with losing touch with the masses lies at the heart of all the Party's anti-bureaucratic rhetoric because it threatens the Party's popular legitimacy.

Bureaucratism was a common target in early-PRC campaigns. Yet Mao decided that these campaigns had not gone far enough, writing in 1960 that: "Bureaucratism, this bad style inherited from old society, must be swept once a year, otherwise it blooms again in the spring breeze." 33 Mao decided there had been "too many meetings, too few contacts with the masses; too many files and reports, too little learning from experiences; too much sitting in the office, too few careful investigations." 34 Zhou's 1963 essay observed that even though the communist revolution had smashed the old regime, it had not completely eradicated bureaucratism, which continued as a remnant of the feudal exploitative class. This is reminiscent of Lenin's remark made five years after the October Revolution that the Russian state had been "overthrown [but] has not yet been overcome." 35

To overcome the state, the seat of bureaucratism, Mao unleashed the Great Proletarian Cultural Revolution, which the Chinese media depicted as "a struggle between two roads, one toward Soviet-style bureaucratic development, and one toward a new Maoist style of non-bureaucratic development."36 The Cultural Revolution's main target was the "elitist, lethargic, careerist bureaucrat, a figure personifying the baneful influence of China's 'feudal' culture." 37

31 See Nathan 1985; Lin 2006.

32 See Lin 2006; Perry 2015. Lenin was equally critical of "bourgeois parliamentarism." Lenin 1992[1918], 41.

33 Mao 1960.

34 Ibid.

35 Lenin 1923. Emphasis added.

36 Whyte 1973, 149.

37 Israel 1973, 15. 
The Cultural Revolution was simultaneously a clarion call against forms of stratification and corruption that had been cloaked by the socialist mirage, and a bellowing roar against the staleness and listlessness of post-revolutionary bureaucratic politics. Oral histories of the Cultural Revolution overwhelmingly capture two sentiments that drove ordinary people to participate in the violent movement: dissatisfaction with stratification and nostalgia for the revolution. ${ }^{38}$ Mao taught that revolution must be energetic and politics must be passionate; bureaucracy, however, is spiritless. Regardless of Mao's intentions in launching the movement, be it a struggle to retake power from Liu Shaoqi or a genuine effort to reinject the state with ideological purification, the mass movement and subsequent purges utterly decimated the state and its functionaries. Yet while the Cultural Revolution saw the CCP's anti-bureaucratic ghost at its strongest, its spirit would persist long after Mao's passing.

\section{The Churning of the Machine}

While China's revolutionary party has always blasted bureaucratism, its revolutionary regime ultimately has had to find a way to coexist with bureaucracy. As Weber observed, bureaucracy is the fate of modern societies, be they democratic or authoritarian, socialist or capitalist. Although revolutions by definition seek the destruction of an old order, they must embark on bureaucratization after seizing power. Leninist parties are, of course, highly bureaucratic creatures. ${ }^{39}$ Martin King Whyte argues that Mao the thinker differed from Mao the practitioner; in practice, he was in fact a "vigorous champion" of bureaucratization as a way to organize social and economic life, although not of rationalization. ${ }^{40}$ In comparison, Mao's successors moved in the direction of rationalization, even though no bureaucracy has ever obtained the status of the Weberian ideal. ${ }^{41}$

Even political campaigns - the poster children of anti-bureaucratic politics rely on bureaucracy to carry them out. ${ }^{42}$ Julia Strauss's study of Land Reform documents that the campaign required "an extraordinary expansion in the capacity of the state." ${ }^{43}$ Kristen Looney's research on rural development campaigns similarly finds that "mass mobilization was intended to transform society so that it would fully support rather than undermine existing bureaucratic structures." 44 However, while state capacity may be high, rational-legality may be low whenever campaigns are the primary mode of policy implementation. Institutional strength - the capacity of bureaucratic institutions to enforce policies - is not

38 See, e.g., Chan, Anita, Rosen and Unger 1980.

39 Leninists believe that state functionaries are necessary in the transitional stage of workers' dictatorship before the state eventually withers away to make room for true democracy. That said, an oligarchic tendency may be located in all political parties according to Michels' (1962[1911]) "iron law of oligarchy."

40 Whyte 1973; 1989.

41 See Yang 2004 for a comprehensive analysis of state reforms after Mao.

42 See Zhou, Xueguang 2017 for an interesting account of how campaign-style implementation can be further traced back to imperial China.

43 Strauss 2019, 207.

44 Looney 2020, 15. 
the same as institutionalization, which is the routinization, normalization and standardization of rule.

But bureaucracies in the PRC have never been mere organizers of periodic campaigns. Even under Mao when mass campaigns were the star of the show, routinized implementation was by no means absent. For example, Ezra Vogel noted in 1970 that "under ordinary circumstances promotions within the apparatus are likely to be based on annual assessment when rational-bureaucratic considerations of competence are given greater weight," even if "at the time of rectification campaigns, promotions and demotions are more likely to be based on political considerations." 45

In the reform era, Elizabeth Perry observes a shift from mass to "managed" campaigns, representing not a clean break from the Mao era but a "complex amalgam" of inherited revolutionary spirit and pragmatic technocratic rule. ${ }^{46}$ This amalgam can be seen in the profile of reform-era ruling elites as "red engineers" whose outlook is both pragmatic and political. ${ }^{47}$

But anti-bureaucratism has never dissipated. Mao's successors have continued to condemn bureaucratism, seeing it as an enduring threat to the Party's connection with the people. Hu Jintao 胡锦涛 cautioned in 1995 that good leaders must "go deep into the masses, understand the mood of the masses, listen to the voices of the masses, care about the sufferings of the masses, and strive to solve practical problems of the masses." 48 The ghost in the machine still finds expression in the Party's personnel decisions, its policy-implementation methods and its persistent interest in intra-Party discipline and anti-corruption.

Critiques of bureaucratism have seen a sharp increase under Xi Jinping, as the ensuing section will demonstrate. Moreover, Xi's critiques of bureaucratism almost always highlight its connection to “formalism" (xingshizhuyi 形式主义) and the lack of substantive governance - one of the four problems highlighted in Zhou's essay on bureaucratism. The Party describes formalism as bureaucratic behaviour that "pursues forms and not effects" (zhuiqiu xingshi, bu zhong shixiao 追求形式, 不重实效). A 2021 Wall Street Journal article explains the gist of “formalism" to its English-speaking readers as "the official epithet for box-ticking and 'CYA' behavior that prioritizes form over substance." 49 The next section will delve further into formalism's connotations and why it has become a major problem.

These critiques of formalism are not merely a product of CCP leaders' ideological predispositions but of identifiable empirical trends. Over the past few years, scholars and observers within China have noted increasing inertia and "formalism" among lower-level bureaucrats. Yet there is a key difference between the ways in which Party theoreticians and Chinese social scientists talk about

49 Wong 2021. 
"bureaucratism" and "formalism." Party theoreticians consistently treat "bureaucratism" as a personal moral failure of individual cadres, in particular a "strong belief in the primacy of officials” (guanbenwei sixiang yanzhong 官本位思想严重) and “distorted view of power" (quanliguan niuqu 权力观扭曲); while formalism is attributed to “misplaced views on political performance” (zhengzhiguan cuowei 政绩观错位) and "lacking a sense of responsibility" (zerenxin queshi 责任心缺失). 50

By contrast, Chinese social scientists have turned to more structural, institutional explanations. Song Xiaoning and Tong Jian attribute contemporary bureaucratism to a major shift in the performance evaluation system, from GDP alone to multiple competing objectives, under which "the completion of one might cause a decline in score on another indicator." 51 For example, cutting industrial capacity for the purpose of environmental protection has led to widespread unemployment in some localities, but social stability, environmental protection and GDP carry equal weight in performance evaluations. In this case, inaction becomes a "rational choice." 52 Others note that when incentives are perverse - for example, when punishment rather than reward drives bureaucrats bureaucratic behaviour becomes distorted. ${ }^{53}$ As a result, Party leaders tend to emphasize thought reform to rectify bureaucratism, whereas scholars are more likely to prescribe institutional remedies.

\section{Dead Letter or Living Faith?}

If an anti-bureaucratic ghost haunts China's bureaucratic machine, how can we tell? This question forces us to confront perennial questions about ideology in political life: does ideology matter? Does it drive "actions" or is it epiphenomenal to "reality"? As Whyte astutely questions, "the frequency with which antibureaucratic rhetoric is aired must give rise to some doubt about the seriousness of the underlying effort." Perhaps "seeming to be opposed to bureaucracy is just one of those rituals that leaders of Leninist systems have to perform periodically ... parallel to denunciations of big government by American presidents." 54 Is the CCP's anti-bureaucratic ideology a "dead letter" we can simply set aside, or a "living faith" by which the regime actually operates? ${ }^{55}$

In this section, we examine the intensity and substance of the Party's antibureaucratic rhetoric over time. If the rhetoric evolves, we may surmise that antibureaucratic ideology is not meaningless ritual, but that it indeed reflects regime reactions to pressing political challenges. Furthermore, if shifting rhetoric nevertheless displays a stable core, we may conclude that anti-bureaucratic ideology

50 "Xingshizhuyi he guanliaozhuyi, you he lianxi? Ruhe qubie" (What is the relationship between formalism and bureaucratism? How can they be differentiated?). Gongchandangyuan wang, 14 May 2020, https://www.12371.cn/2020/05/14/ARTI1589435154642263.shtml. Accessed 9 September 2021.

51 Song and Tong 2019, 129.

52 Ibid.

53 Ni and Wang 2017; Ma and Ma 2021.

54 Whyte 1989, 237.

55 Schwartz 1951, 2. 
still constitutes a living faith, even if, or precisely because, actual practice often deviates from it.

We use three types of data to examine transformations in the Party's antibureaucratic ideology. In addition to speeches by leaders and writings by intellectuals, we turn to People's Daily (Renmin ribao 人民日报). The Party's official newspaper, People's Daily is where the Party articulates its ideologies and communicates its policies. It is thus widely used in studies of official discourse. ${ }^{56} \mathrm{We}$ analyse the entire available corpus of People's Daily articles between 1947 and 2020 (approximately 1.9 million total). ${ }^{57}$ Of those 1.9 million articles, 14,667 mention "bureaucratism" - an average of 198 per year. We carefully read a random sample of 736 articles on bureaucratism stratified by year of publication (about 5 per cent of all articles that mention bureaucratism). All 736 condemn bureaucratism, suggesting that this word is always used as a pejorative. We then pair our qualitative interpretation with quantitative text analysis.

To track the intensity of the Party's anti-bureaucratic rhetoric, we use a simple word count of "bureaucratism," normalized by the word count of "government," in each year. ${ }^{58}$ The line in Figure 1 shows the intensity of anti-bureaucratic rhetoric in the People's Daily between 1947 and 2020. Mentions of "bureaucratism" peaked during the Three Anti and Five Anti campaigns in the early 1950s, when "bureaucratism" was one of the nominal targets of the Three Anti's (alongside anti-corruption and anti-waste). The early 1950s was also a period of regime consolidation, when the Party sought to eradicate its perceived rivals, including landlords, private entrepreneurs and anyone who worked for the old regime. After this initial spike, mentions of bureaucratism peaked again during the 1957 Anti-Rightist Campaign, the Cultural Revolution, and in the mid-1980s when economic reform produced massive corruption and inequality. Anti-bureaucratic rhetoric declined in the 1990s and 2000s under Jiang Zemin 江泽民 and $\mathrm{Hu}$ Jintao, before making a strong return in recent years under $\mathrm{Xi}$ Jinping. But even during the two decades of the Jiang and $\mathrm{Hu}$ administrations, anti-bureaucratism never went away: an average of 122 articles mentioned it per year.

While informative, frequency of words does not tell us the full story. For instance, the intensity of Xi's anti-bureaucratic rhetoric has led some to compare him to Mao, but careful observers note major differences - for instance, Xi's eschewing of the rhetoric of class struggle and mass mobilization. Andrew Walder argues that while "[wielding] the symbolism" of Mao's antibureaucratism, $\mathrm{Xi}$ is in fact a "lifelong bureaucrat for whom political stability

56 See, e.g., Wu 2014; Chan and Zhong 2018; Ang 2020, Ch. 3.

57 We dropped 1946 and 2021 because our analysis relies on complete data from each year; the first issue of the People's Daily was in May 1946, and data for 2021 is incomplete.

58 Following prevailing practice, we normalized word counts by dividing them by counts of "government" (zhengfu) to account for potential over time variation in the length of the newspaper (see, e.g., Ang 2020, 220). 
Figure 1: Intensity of "Bureaucratism" in People's Daily

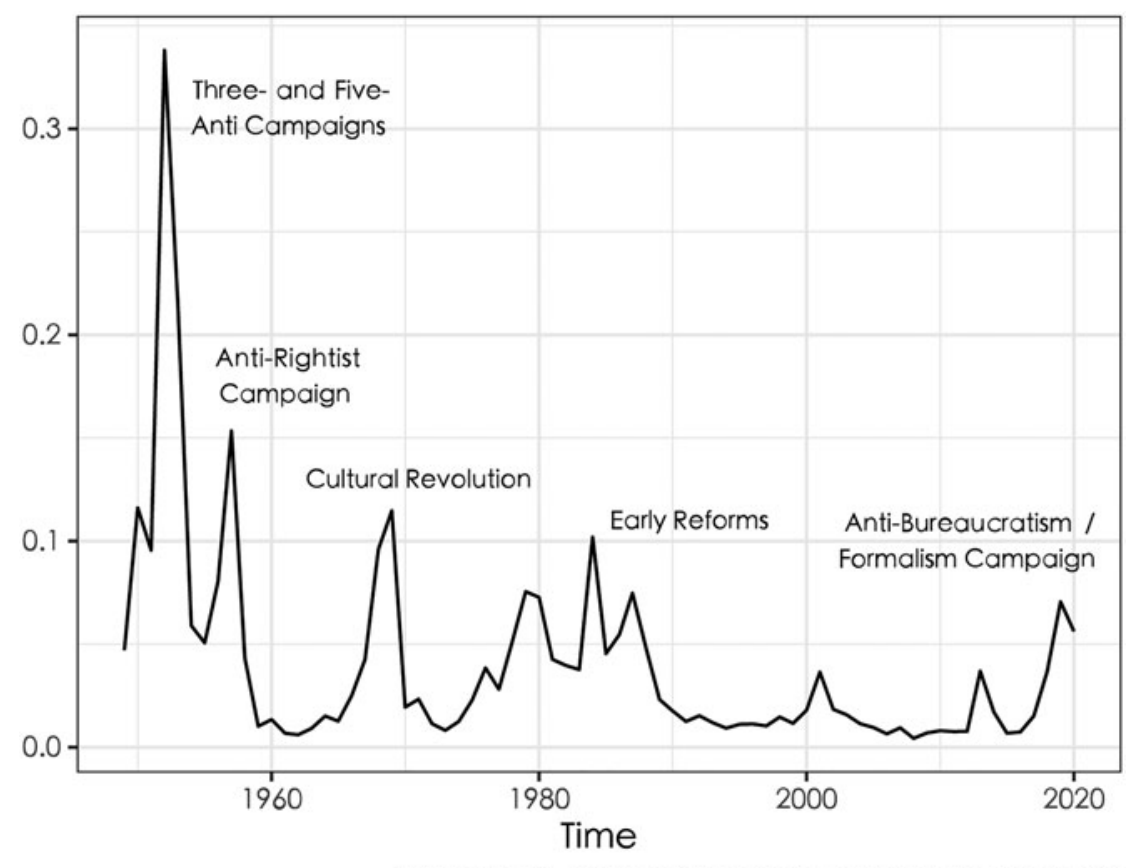

Annual term counts divided by counts of 'government'

and economic progress are the highest goals." 59 But if $\mathrm{Xi}$ is a prototypical bureaucrat, why does he condemn bureaucratism with such ardour? Is "bureaucratism" simply a synonym for corruption, given Xi's signature anti-corruption campaign, or is there more to it than that?

To examine the substance and evolution of anti-bureaucratism, we combine qualitative interpretation with quantitative text analysis. Specifically, to approximate the meaning of "bureaucratism," we identify terms with the highest probabilities of appearing alongside it in the same sentence in the People's Daily. ${ }^{60}$ This method comes from the "distributional" hypothesis of linguistics: "you shall know a word by the company it keeps."61 We use "context word" to refer to the words that keep "bureaucratism" company. Our quantity of interest is the probability of a context word appearing, conditional on our keyword ("bureaucratism") appearing. We estimate the probability of co-occurrence by

59 Walder 2018, 21.

60 Alternatively, one may examine co-occurrence at the paragraph or article level. Given the structure of our corpus, a paragraph-level approach was infeasible. Between sentence and article levels, we believe the first is preferable because it generates more accurate estimates of the contextual meaning of "bureaucratism."

61 Firth 1957, 11. 
counting all words that appear with "bureaucratism" in the same sentence, then dividing those counts by the total number of times "bureaucratism" appears in the same time interval. ${ }^{62}$ This procedure is essentially the maximum likelihood estimate of bigram probability, with the slight modification that all other words in the sentence are considered instead of words that just follow one another directly. 63

Expressed formally, if $x$ is our keyword of interest ("bureaucratism") and $y$ is a context word, and $x, y$ denotes the two appearing in the same sentence, we estimate $P(y \mid x)=C(x, y) / C(x)$, where $C(x)$ is the number of times "bureaucratism" appears, and $C(x, y)$ is the number of times "bureaucratism" and the context word co-occur in the same sentence within the same time period. This analysis allows us to estimate smoothed co-occurrence probabilities overtime, from which we draw the 30 most likely words to appear with "bureaucratism." 64

Figures 2 and 3 show these words, estimated separately for the Mao era and the post-Mao era, as well as the shifting probabilities of their co-occurrence.

The co-occurrence probabilities in Figures 2 and 3 show that "bureaucratism" is depicted in People's Daily articles as a faulty "[work] style" (zuofeng 作风) of “cadres" (ganbu 干部) and "leadership" (lingdao 领导) that must be emphatically “opposed” (fandui 反对) and “overcome” (kefu 克服). It was to be “struggled against" (douzheng 斗争) in the Mao era and needs to be "resolved" (jiejue 解 决) in the reform era.

Anti-bureaucratic rhetoric is always tied to the notion of the people: "people" (renmin 人民) or “masses" (qunzhong 群众) can be found as top words co-occurring with "bureaucratism" in both eras. Close readings of the articles show that critiques of bureaucratism persistently accompany anxieties that decision making will become "detached from the people" (tuoli qunzhong 脱离群众), “detached from reality” (tuoli shiji 脱离实际), with cadres no longer caring about “the interest of the people" (qunzhong liyi 群众利益).

As a "work style" (gongzuo zuofeng 工作作风), the Party sees bureaucratism as reflecting the moral failure of individual cadres, and thus it can be rectified by selfcultivation and increasing contacts with the people. For example, a 1974 opinion written by a cadre confesses that his past mistake of bureaucratism was rectified by participating in production alongside the workers. Workers purportedly told him "[in the past] we did not dare approach you. Now we can call you 'Old Liu' and can chat with you often and heart-to-heart. What a change!'65 This emphasizes the Party's ultimate worry that bureaucratism threatens its popular legitimacy.

62 We segment sentences into words using the jieba python library. Documentation is available at https:// github.com/fxsjy/jieba. We also remove "stop words," which are normally grammatical particles or "helping" words that occur so often as to be unhelpful in determining meaning.

63 See Jurafsky and Martin 2020.

64 To ensure that there are sufficient uses of the keyword to make reasonable estimates of co-occurrence probability, we use a sliding three-year window of People's Daily articles (e.g., 1946-1948, then 1947-1949, then 1948-1951, and so on, until 2018-2020).

65 Liu, Runwu 1974. 
Figure 2: Words Co-occurring with "Bureaucratism" in the Mao Era, 1947-1976

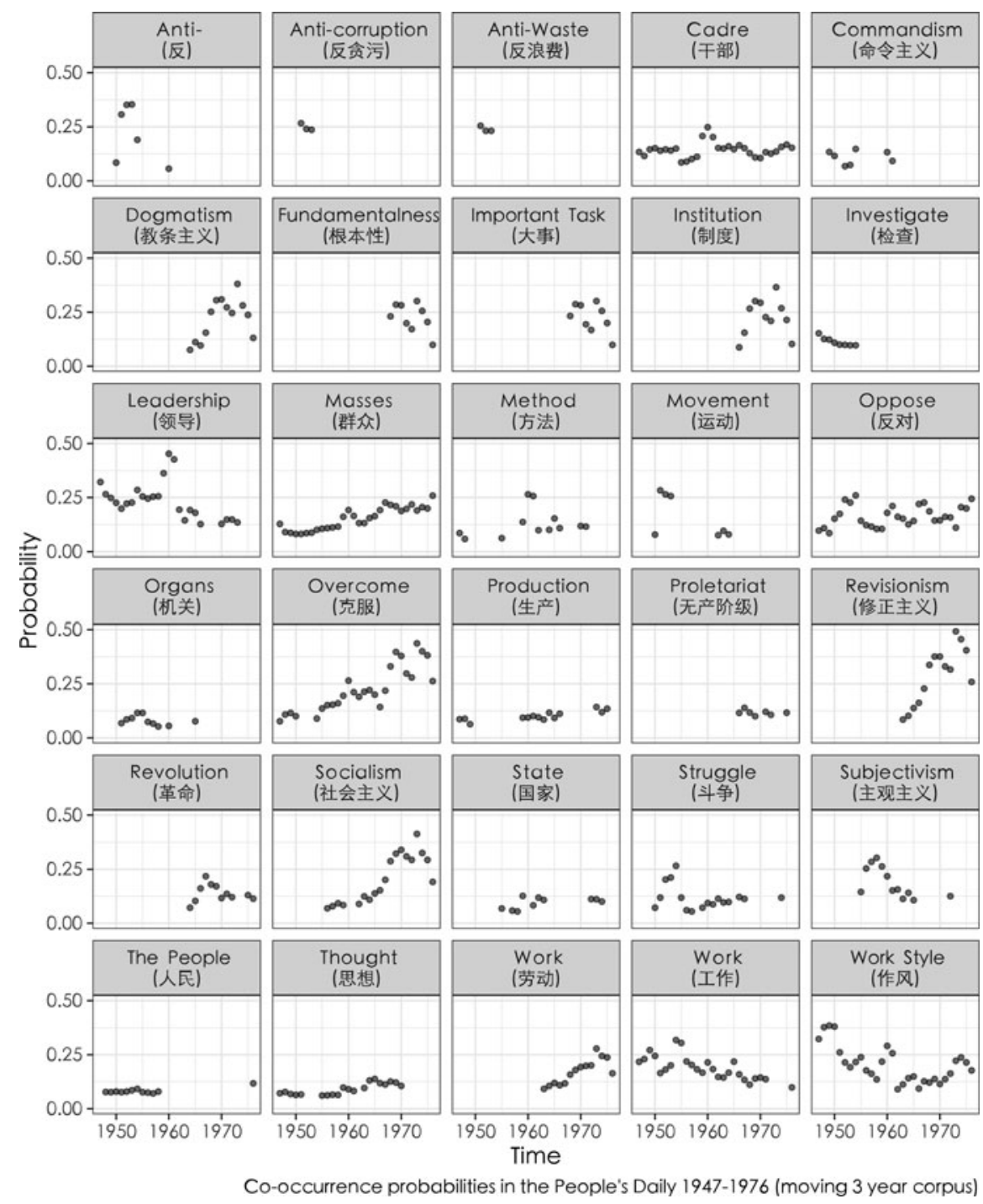

We also find gradual shifts in the CCP's anti-bureaucratic rhetoric, reflecting different challenges the Party faced at different historical points. In the early PRC, bureaucratism often appeared alongside "imperialism" (diguozhuyi 帝国主 义) and “feudalism" (fengjianzhuyi 封建主义), and it was often described as an “old thing” ( jiu dongxi 旧东西) to be discarded. Figure 2 shows that under Mao, bureaucratism was closely tied to "commandism” (minglingzhuyi 命令主义), "subjectivism” (zhuguanzhuyi 主观主义), “revisionism” (xiuzhengzhuyi 修正主义) and "dogmatism" (jiaotiaozhuyi 教条主义). But there are also subtle shifts in 
Figure 3: Words Co-occuring with "Bureaucratism" after Mao, 1977-2020

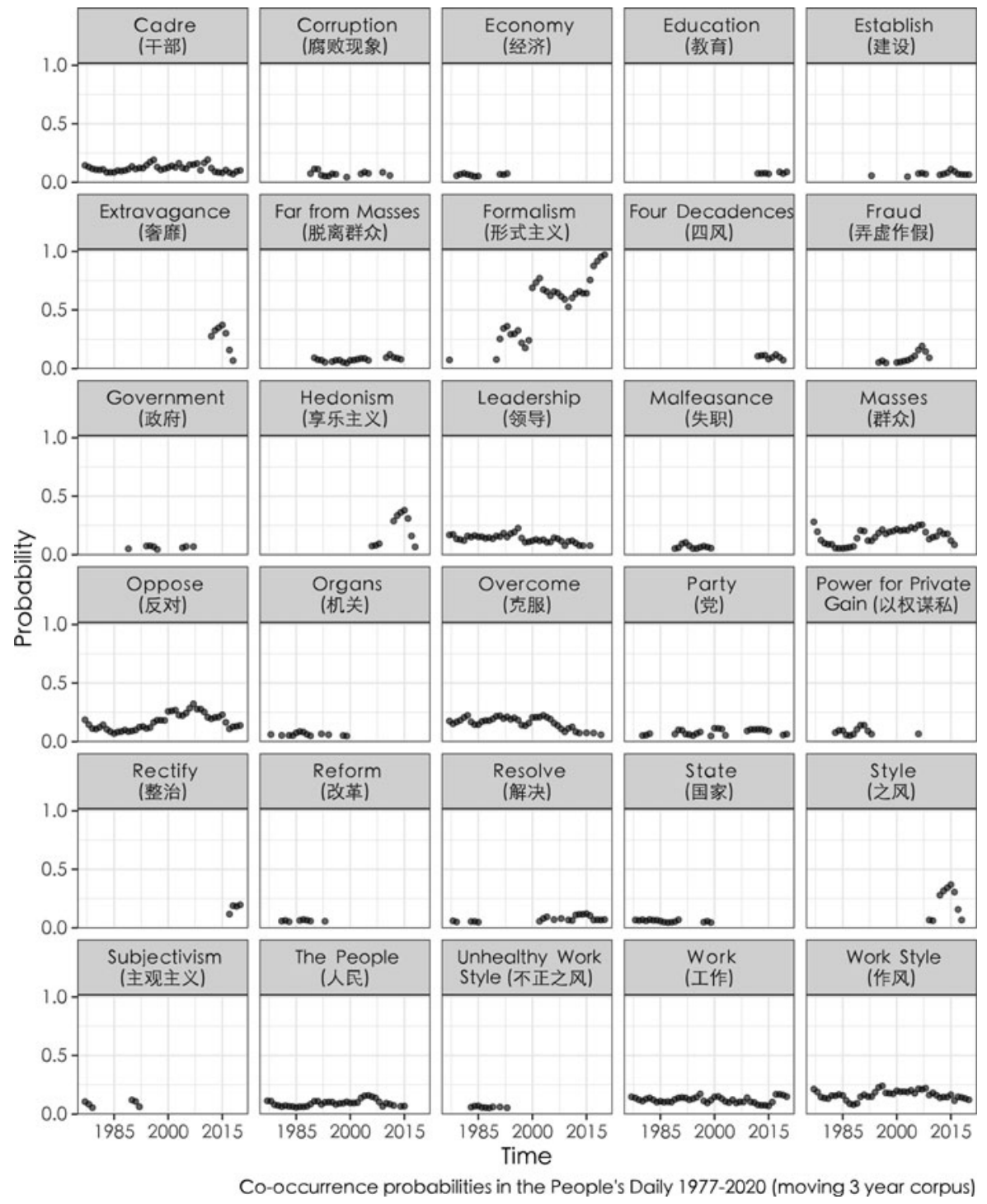

emphasis. Before the Cultural Revolution, anti-bureaucratic critiques concentrated on "subjectivism" and "commandism." During the Cultural Revolution, concerns shifted to Soviet "revisionism" and theoretical "dogmatism."

Figure 3 shows the evolution of anti-bureaucratism after Mao. Three features stand out in this graph and in our qualitative reading. First, with marketization, conspicuous consumption and vast corruption, there was a vivid rise in association between "bureaucratism" and terms describing the "unhealthy style" (buzheng zhi feng 不正之风) of cadres, such as “fraud” (nongxuzuojia 弄虚作假), 
“extravagance” (shemi 奢靡), and “hedonism” (xianglezhuyi 享乐主义). Turning our attention back to Figure 1, discussions of "bureaucratism" rose in the 1980s, speaking to the vast corruption that emerged during market transition. It peaked again during Xi's anti-corruption campaign which took aim at the "hedonism" and "extravagance" of corrupt cadres.

Second, terms that co-occur with bureaucratism seem to have become more legalistic. For example, “corruption phenomenon” (fubai xianxiang 腐败现象), “malfeasance” (shizhi 失职) and “[political] power for private gain" (yiquan mousi 以权谋私) are increasingly used to describe corruption. This supports the intuition that anti-corruption efforts, like many other aspects of Chinese governance, are no longer exerted through mass mobilization but are channelled through formal-legal institutions. ${ }^{66}$

Third, and most strikingly, we see a clear spike in the association of "bureaucratism" with "formalism." By 2020, all mentions of "bureaucratism" in the People's Daily are accompanied by "formalism," and formalism even surpasses "bureaucratism" in the number of mentions. Although "formalism" appears earlier, such as in Zhou's 1963 essay and other leaders' speeches as well as People's Daily reporting, it is not until the reform era, and particularly so in recent years, that it has become a central concern of the Party, appearing almost hand-in-hand with "bureaucratism" (see Figure 4).

What is formalism and why has it become a growing worry for the CCP? China's communist revolutionaries originally adopted the term from European and Russian Marxists. ${ }^{67}$ In Soviet Russia, for instance, anti-formalism campaigns under Stalin targeted arts that were believed to have focused on aesthetic forms over substantive content; however, since the only permissible content was that which adhered to the Party line, this "anti-formalism" ironically turned into another kind of formalism.

Chinese revolutionaries used "formalism" to refer to "feudalistic ritual behavior, aesthetic ornamentalism, empty rhetorical abstraction ... [and] calcified institutional practices."68 In People's Daily, formalism appears alongside "empty talk” (konghua 空话), “word games” (wenzi youxi 文字游戏), “mountains of documents and oceans of meetings" (wenshanhuihai 文山会海), “complicated procedures” (chengxu fuza 程序复杂) and other performativity used by lowerlevel bureaucrats to deal with directives from upper-level authorities. In Xi Jinping's words, formalism is the practice that "replaces concrete implementation with garish forms" and "covers up tensions and problems with a glamorous appearance" (yong honghonglielie de xingshi daitile zhazhashishi de luoshi, yong

66 Whether legal institutions provide a mere veneer of legitimacy or substantive "rule of law" is a question beyond the scope of this study.

67 The discussion of formalism goes further back in the German intellectual tradition. Weber, for instance, uses "formalism" as a neutral term to represent bureaucratic rationalization.

68 Chan, Roy 2019, 77. 
Figure 4: Instances of "Bureaucratism" and "Formalism" in People's Daily

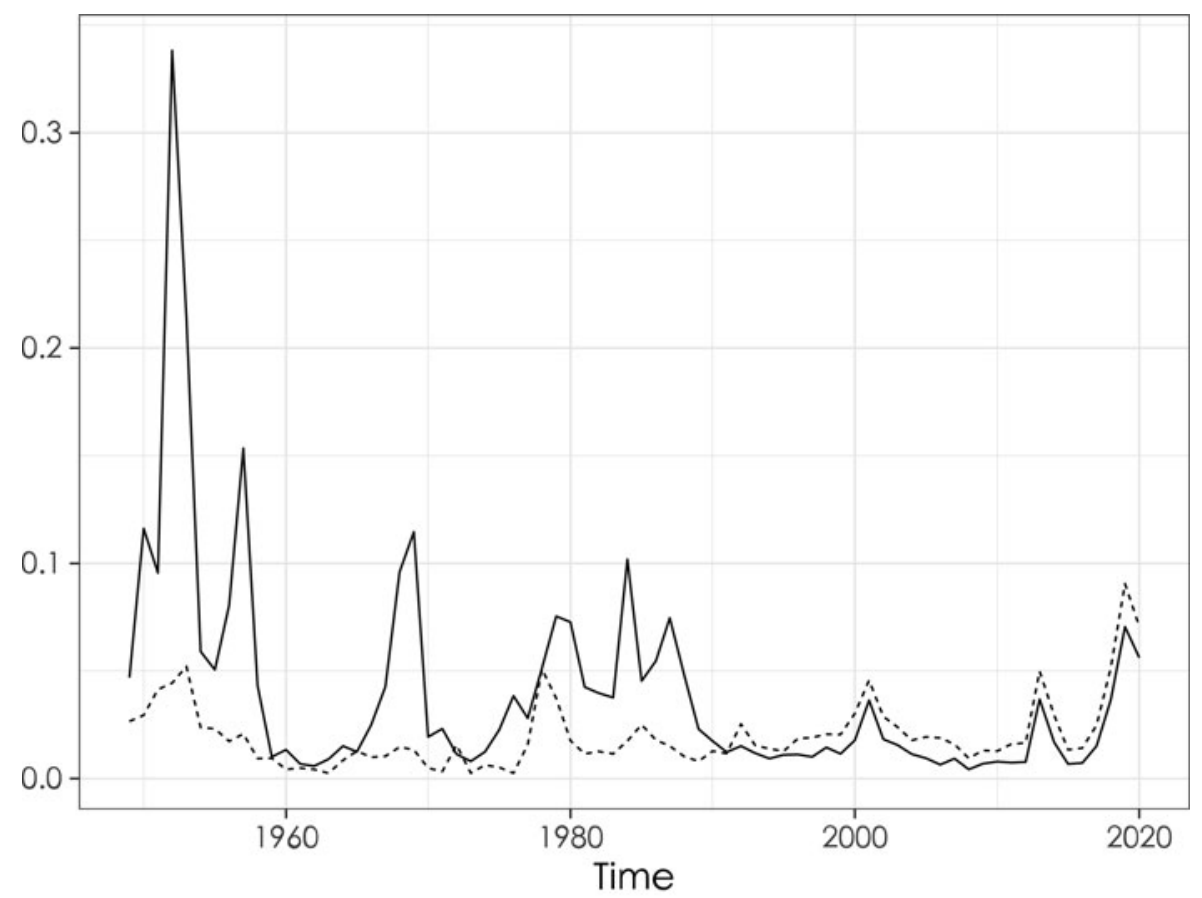

— Bureaucratism (官僚主义) …. Formalism (形式主义)

Annual term counts divided by counts of 'government'

guangxianliangli de waibiao yan'gaile maodun he wenti 用轰轰烈烈的形式代替了 扎扎实实的落实, 用光鲜亮丽的外表掩盖了矛盾和问题). ${ }^{69}$ The divorce of formalistic procedures from substantive results is a problem extensively discussed in Weber's writings on rational bureaucracy. For a party that legitimizes itself by critiquing the inability of Western institutional forms to deliver the substantive results of better lives, formalism presents a major challenge. Xi warns that if such workstyle is not corrected, the Party will "lose people's hearts and lose power."70

Although formalism has always been a part of the CCP's vernacular, its recent ascendence is curious. In 2013, Xi named formalism as the first of the "four decadences” (sifeng wenti 四风问题), alongside bureaucratism, hedonism and

69 “'Zhengzhi xingshizhuyi guanliaozhuyi jiaoyu duben' xuanzhai: shenme shi xingshizhuyi, guanliaozhuyi? Ni zhende liaojie ma?" (Selections from the "Rectifying formalism and bureaucratism reader": what are formalism and bureaucratism? Do you really understand them?). Renminwang, 7 May 2020, http://fanfu.people.com.cn/n1/2020/0507/c64371-31700033.html. Accessed 9 September 2021.

70 “Lijie xingshizhuyi, guanliaozhuyi, zongshuji you naxie lunshu?" (What are the general secretary's treatises against formalism and bureaucratism?). Gongchandangyuan wang, 11 March 2019, https://www. 12371.cn/2019/03/11/ARTI1552304221566909.shtml. Accessed 9 September 2021. 
extravagance (see Figure 3). An article on the Party's official website denounces both formalism and bureaucratism while drawing fine distinctions between them: "formalism plagues both upper-level and street-level (jiceng 基层) [bureaucrats]," while "bureaucratists are mostly upper-level cadres," but "more often, [formalism and bureaucratism] are in bed with each other."71

Yet "formalism" is not merely a metaphysical abstraction conjured up by Party theoreticians. Rather, it reflects increasing recognition of policy implementation being ineffective and symbolic. Lower-level bureaucrats have learned to "look busy" without actually implementing higher-ups' directives. ${ }^{72}$ During the recent poverty alleviation campaign, observers found that cadres limited their efforts to filling out forms, taking (sometimes staged) pictures, and "walking through the scene" (zouguochang 走过场), all to leave traces of one's efforts, a practice also known as "trace-ism" (henjizhuyi 痕迹主义).

The Party seeks to rectify formalism and bureaucratism through political education. Meanwhile, scholars argue that bureaucrats engage in formalism not because they want to, but because they have to: as they face impossible demands from above with limited resources, bureaucrats use formalism as a means of blame avoidance. In their 2018 survey of poverty alleviation cadres, Wang Yahua and Shu Quanfeng found overwhelming "burnout" among cadres sent to the countryside to implement the poverty alleviation campaign, with nearly 80 per cent of them reporting physical and psychological exhaustion. ${ }^{73}$

Wang Enxue describes this phenomenon as "grassroots fatigue" (jiceng pibei 基层 疲忞). ${ }^{74}$ His widely circulated opinion piece documents the excessive burdens shouldered by street-level bureaucrats owing to a "dramatic increase in ideological work ... growing number of new tasks, new responsibilities, new demands ... having to answer to multiple upper-level [bureaucratic] 'mother-in-laws' ... [and] a vast amount of repetitive work." These burdens lead in turn to "passiveness ... fatigue ... poor mood ... complaints" and the "mechanical implementation" of policies. Wang, warning against the "resurgence of formalism," urges central authorities to pay attention to the strains plaguing street-level bureaucrats. ${ }^{75}$

Other scholars, like Fang Ning, argue that preventing formalism requires upper-level officials to allow flexibility and discretion to those bureaucrats responsible for implementing policies. ${ }^{76}$ Fang diagnoses "formalism" as a symptom of rigid planning and unreasonable expectations set by upper-level authorities who fail to appreciate the "lack of resources and funds at the street level."77

71 "Xingshizhuyi he guanliaozhuyi, you he lianxi? Ruhe qubie" (What is the relationship between formalism and bureaucratism? How can they be differentiated?). Gongchandangyuan wang, 14 May 2020, https://www.12371.cn/2020/05/14/ARTI1589435154642263.shtml. Accessed 9 September 2021.

$72 \mathrm{Ni}$ and Wang 2017, 48.

73 Wang, Yahua, and Shu 2018.

74 Wang, Enxue 2017.

75 Ibid.

76 Fang 2020.

77 Li 2019. 


\section{Figure 5: Intensity of "Institutionalization," "Normalization" and "Standardization" in the People's Daily}

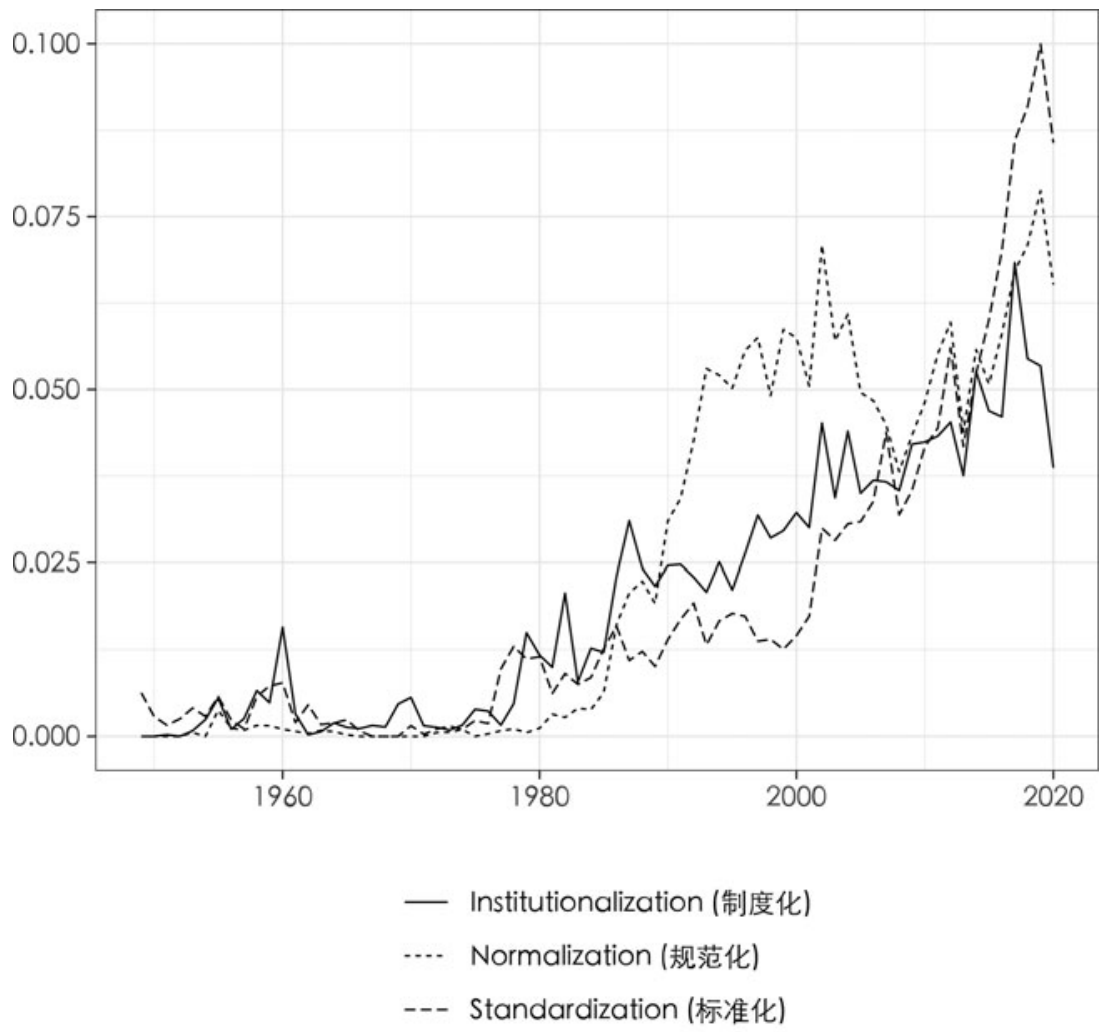

Annual term counts divided by counts of 'government'

Overall, scholarly discussion of formalism does not place blame on individual morality or the lack of revolutionary spirit. Instead, the focus is on the excessive demands and perverse incentives faced by street-level bureaucrats. This phenomenon is explored in broader research as "bureaucratic slack" and "performative governance."78

These observations eventually led the Party to announce a "Grassroots burden reduction year” (jiceng jianfu nian 基层减负年) in 2019 through a Central Committee Decree. ${ }^{79}$ The Decree demanded a ten-page limit to policy documents, a 30 to 50 per cent reduction in the number of documents and meetings

78 See, e.g., Ding 2020; Wang, Peng, and Yan 2020; Wang, Erik 2021.

79 "Zhonggong zhongyang bangongting yinfa 'Guanyu jiejue xingshizhuyi tuchu wenti wei jiceng jianfu de tongzhi" (Notice from the General Office of the Central Committee of the CCP on "Solving the outstanding problems of formalism and reducing the burdens on the grassroots). Xinhua, 11 March 2019, http://www.gov.cn/zhengce/2019-03/11/content_5372964.htm. Accessed 9 September 2021. 
at the county level, and a significant reduction in the amount of supervision. Such steps sought to rectify the problems of "mountains of documents and oceans of meetings" and of "too many supervisions and performance evaluations." These concerns resonate with the part of Zhou Enlai's essay on bureaucratic inefficiency and ineffectiveness. And the drastic nature of the policy response suggests that anti-bureaucratism is more than empty rhetoric.

Rising anxieties over "formalism" are also indicative of an under-appreciated development after Mao: efforts to institutionalize and even rationalize Chinese bureaucracies. Formalism may take "forms" to an extreme, but without "forms," there would not be any formalism to speak of. Figure 5 shows normalized annual counts of “institutionalization" (zhiduhua 制度化), “standardization” (biaozhunhua 标准化) and “normalization” (guifanhua 规范化), which are all features of bureaucratic rationalization. Mentions of these terms steadily increase in the post-Mao era.

A sceptic may again question whether all of these words are "cheap talk." Expressing interest in rational bureaucracy is not the same as having a rational bureaucracy. While it is beyond the scope of our study to demonstrate the transformation of Chinese bureaucracy, the very minimum these trend lines indicate is that, contrary to conventional wisdom, the CCP's interest in institutionalization has not declined under $\mathrm{Xi}$. What differentiates $\mathrm{Xi}$ from his predecessors is how emphatically and explicitly he has brought the ghost of anti-bureaucratism back into China's bureaucratic machine.

\section{Conclusion}

Writing at the end of the Mao era, Harry Harding posited that CCP leaders faced a "philosophical dilemma ... do the efficiency and rationality of modern bureaucracy outweigh the social and political costs that bureaucratization may impose?" 80 This "dilemma" of modernity has been the subject of a lasting wealth of social science literature. It was a fascination of Marx and Weber. It puzzled the state-builders of the PRC.

This article documents the persistence and transformation of the revolutionary Party's anti-bureaucratic spirit as it finds its way as a ruling regime. Liu Shaoqi's 1939 warning that the CCP must avoid previous revolutionaries' mistake of succumbing to bureaucratism after taking power still haunts the Party today. "Bureaucratism" remains a core ideological concern of the Party because of the threat it poses to the regime's popular legitimacy. But different periods have witnessed different challenges. Under Mao, "bureaucratism" was used to critique first the old society, then Soviet revisionism and its Chinese sympathizers. After Mao, "bureaucratism" reflects the Party's trepidation about corruption and policy mis-implementation. 
CCP leaders continue to navigate the tension between bureaucratization and anti-bureaucratism because it constitutes, in their conception, the very dilemma of single-party governance. Mao rejected bureaucratic rationalization only to see the steep human costs of keeping the revolutionary spirit alive. Mao's successors have embraced modernization and rationalization only to witness the challenges that they bring in turn. But at no point in time (perhaps with the exception of the Cultural Revolution) has the CCP abandoned this fine balancing act of carrying, on both shoulders, ideology and institutions, revolution and rationality, substantive ends and procedural means. The ghost remains as real as the machine. This balancing act appears to be a tension in theory, but it may well be a source of the Party's resilience in practice.

What's the use of examining rhetoric when it can often depart so far from actual practice? Perhaps the point lies precisely in identifying the gap between rhetoric and reality. As Frederic Wakeman puts it, "Ideologies remain vital not because they coincide with reality, but rather because those who believe in them know that while reality merely is, they would will it otherwise." 81 This will to alter reality, in turn, constitutes a new reality in its own right. In the case of China, the repeated use of anti-corruption campaigns and the constant shaking up of state bureaucracies are but the best evidence of continuing anti-bureaucratic politics in action.

Nevertheless, intense anti-bureaucratic rhetoric and practices unfold in parallel fashion with efforts at institutionalization - even under Xi Jinping, when ideology and loyalty are believed to trump institutions and rationality. This, if anything, suggests the limitations to all kinds of "either/or" questions regarding China. Ideology and institutions need not always be at each other's throats, the theoretical tensions so astutely articulated by the Party's intellectual forebears notwithstanding.

\section{Acknowledgements}

The authors thank Ling Chen, Shuang Chen, Yanhua Deng, Josh Freedman, Xiang Gao, Kyle Jaros, Junyan Jiang, Parker Koch, Daniel Koss, Jeff Lockhart, Fengming Lu, Zhaotian Luo, Xiao Ma, Brendan McElroy, Elizabeth Perry, Meg Rithmire, Christian Sorace, Patricia Thornton, Yuhua Wang, Xiaohong Xu, John Yasuda, Yang Zhang, Ying Zhang, Xueguang Zhou and participants of the Political Science Speaker Series for their helpful feedback.

\section{Conflicts of interest}

None. 


\title{
Biographies
}

Iza DING is assistant professor of political science at the University of Pittsburgh. Her research explores the antinomies emerging through economic and political modernization, such as development and environmentalism, bureaucracy and populism, and liberalism and nationalism. Her articles have appeared in Comparative Political Studies, Chinese Political Science Review, Democratization, Studies in Comparative and International Development and World Politics. Her forthcoming book, The Performative State: Public Scrutiny and Environmental Governance in China, is to be published by Cornell University Press.

Michael THOMPSON-BRUSSTAR is a $\mathrm{PhD}$ candidate in political science at the University of Michigan. His research examines bureaucratic control and the evolution of legal-administrative institutions in China.

\begin{abstract}
提要: 中国共产党的意识形态源自其革命斗争历史, 其中明确谴责了“官僚 主义”, 认为它是官僚组织的㽽疾。然而, 由于官僚制是有效治理的必要 条件, 革命政党尽管始终保持对官僚主义的警惕, 却又不得不寻求与官僚 机器共存的方式。于是, 一个反官僚主义的幽灵始终索绕着中国的国家机 器。我们分两步分析了中国共产党的反官僚主义意识形态。首先, 我们采 用历史分析回顾了党的反官僚主义思想, 厘清了其根源于马克思列宁主义 又不同于经典马列主义的实质内涵。其次, 我们深度解读并运用量化文本 分析系统考察了《人民日报》（1947-2020）语料库, 追溯了党在反官僚 主义意识形态中话语的延续及演变。我们发现, 中共反官僚主义意识形态 的实质存在惊人的延续性, 同时又由于不同时期的治理挑战出现了微妙的 转变。具体而言, 反官僚主义的意识形态始终体现了党对执政合法性基础 的关注。其着眼点则从毛时代的命令主义与修正主义, 逐步转变为改革开 放后的腐败与形式主义。有趣的是, 党对官僚主义、形式主义的批评与它 在国家建设中推动的标准化、规范化和制度化正同步发生。
\end{abstract}

关键词: 中国; 官僚制; 官僚主义; 形式主义; 意识形态; 革命; 国家; 制度; 制 度化

\section{References}

Andreas, Joel. 2009. Rise of the Red Engineers: The Cultural Revolution and the Origins of China's New Class. Stanford, CA: Stanford University Press.

Ang, Yuen Yuen. 2020. China's Gilded Age: The Paradox of Economic Boom and Vast Corruption. London: Cambridge University Press.

Chan, Anita, Stanley Rosen and Jonathan Unger. 1980. "Students and class warfare: the social roots of the Red Guard conflict in Guangzhou (Canton)." The China Quarterly 83, 397-446.

Chan, Roy. 2019. "Formalism.” In Christian Sorace, Ivan Franceschini and Nicholas Loubere (eds.), Afterlives of Chinese Communism: Political Concepts from Mao to Xi. Canberra: ANU Press, 77-80.

Chen, Yan. 1995. "Hu Jintao zai xian (shi) wei lingdao jingji jianshe jingyan jiaoliuhui shang qiangdiao zaojiu dapi gaosuzhi lingdao rencai, lingdaoganbu yao zhongshi xuexi shanyu xuexi shanyu 
lingdao" (Hu Jintao emphasizes training many high-quality cadres requires cultivating skills of learning and leadership). People's Daily, 11 February.

Ding, Iza. 2020. "Performative governance." World Politics 72(4), 525-556.

Fang, Ning. 2020. "'Dingge guanli' bi de jiceng gao xingshizhuyi” (Top-down management pressures grassroots to engage in formalism). Aisixiang, 12 June, https://www.aisixiang.com/data/121695. html. Accessed 9 September 2021.

Firth, John Rupert. 1957. Papers in Linguistics, 1934-1951. London: Oxford University Press.

Han, Yanming. 2020. "Mao Zedong tan kongzi" (Mao Zedong on Confucius). Renminwang, 10 November, http://dangshi.people.com.cn/n1/2020/1110/c85037-31924951.html. Accessed 9 September 2021.

Harding, Harry. 1981. Organizing China: The Problem of Bureaucracy, 1949-1976. Stanford, CA: Stanford University Press.

Hearn, Francis. 1978. "Rationality and bureaucracy: Maoist contributions to a Marxist theory of bureaucracy." The Sociological Quarterly 19(1), 37-54.

Israel, John. 1973. "Continuities and discontinuities in the ideology of the Great Proletarian Cultural Revolution.” In Chalmers Johnson (eds.), Ideology and Politics in Contemporary China. Seattle, WA: University of Washington Press, 3-46.

Jackson, William A. 1999. "Dualism, duality and the complexity of economic institutions." International Journal of Social Economics 26(4), 545-558.

Jurafsky, Dan, and James Martin. 2020. Speech and Language Processing. Available at stanford.io/ 3uktA6j.

Lenin, Vladimir. 1992[1918]. The State and Revolution. London: Penguin Twentieth Century Classics.

Lenin, Vladimir. 1923. "Better fewer, but better," https://www.marxists.org/archive/lenin/works/1923/ mar/02.htm.

Li, Ling. 2019. "Fang Ning: meiyou tiaojian ying yao shang, zenneng bu xingshizhuyi?" (Fang Ning: without necessary conditions, how can there not be formalism?). Guanchazhe, 3 April, https://www. guancha.cn/FangNing/2019_04_03_496159.shtml. Accessed 9 September 2021.

Lin, Chun. 2006. The Transformation of Chinese Socialism. Durham, NC: Duke University Press.

Liu, Runwu. 1974. 'Wuchanjieji wenhua dageming shenshen jiaoyu le wo" (The Great Proletariat's Cultural Revolution has deeply educated me). People's Daily, 11 September.

Liu, Shaoqi. 1939. "How to be a good communist," https://www.marxists.org/reference/archive/ liu-shaoqi/1939/how-to-be/ch01.htm. Accessed 9 September 2021.

Looney, Kristen E. 2020. Mobilizing for Development: The Modernization of Rural East Asia. Cornell, NY: Cornell University Press.

Ma, Xiao, and Jialei Ma. 2021. "Keceng jili jiegou de yingzi: jiceng zhili zhong zhengce zhixing bianxing de leixing yu chengyin" (Shadow of bureaucratic incentive structure: types and causes of policy implementation distortion in grassroots governance). Working paper.

Mao, Zedong. 1930. "Xunwu diaocha" (Xunwu investigation), http://marxistphilosophy.org/ maozedong/mx1/027.htm. Accessed 9 September 2021.

Mao, Zedong. 1933. "Bixu zhuyi jingji gongzuo" (On the importance of economy), https://www. marxists.org/chinese/maozedong/marxist.org-chinese-mao-19330812.htm. Accessed 9 September 2021.

Mao, Zedong. 1960. "Fandui guanliaozhuyi, kefu "wuduo wushao"” (Anti-bureaucratism: overcome five excesses and five lackings), http://marxistphilosophy.org/maozedong/mx8/033.htm. Accessed 9 September 2021.

Michels, Robert. 1962[1911]. Political Parties: A Sociological Study of the Oligarchical Tendencies of Modern Democracy. (Eden and Cedar Paul (trans.)). New York: Free Press.

Nathan, Andrew J. 1985. Chinese Democracy. Berkeley, CA: University of California Press.

Nelson, Laura. 2017. "Computational grounded theory: a methodological framework." Sociological Methods and Research 49(1), 3-42.

$\mathrm{Ni}$, Xing, and Rui Wang. 2017. "Cong yaogong dao bize: jiceng zhengfu guanyuan xingwei bianhua yanjiu" (From credit claiming to blame avoidance: an analysis of the changing behaviour of grassroots officials). Zhengzhixue yanjiu 2, 44-53. 
Perry, Elizabeth J. 2007. Patrolling the Revolution: Worker Militias, Citizenship, and the Modern Chinese State. Lanham, MD: Rowman and Littlefield.

Perry, Elizabeth J. 2011. "From mass campaigns to managed campaigns: 'constructing a new socialist countryside'." In Sebastian Heilmann and Elizabeth J. Perry (eds.), Mao's Invisible Hand: The Political Foundations of Adaptive Governance in China. Cambridge, MA: Harvard University Press, 30-61.

Perry, Elizabeth J. 2015. "The populist dream of Chinese democracy.” The Journal of Asian Studies 74 (4), 903-915.

Ryle, Gilbert. 2009[1949]. The Concept of Mind. Abingdon: Routledge.

Schurmann, Franz. 1968. Ideology and Organization in Communist China. Berkeley, CA: University of California Press.

Schwartz, Benjamin I. 1951. Chinese Communism and the Rise of Mao. Boston, MA: Harvard University Press.

Song, Xiaoning, and Jian Tong. 2019. “'Lanzheng,' zonghe zhengji kaohe yu zhengfu jigou gaige” ("Lazy governance," performance evaluation and bureaucratic reform). Jingji shehui tizhi bijiao 2, 127-133.

State Council Information Office. 2020. "Xuexi 'Xi Jinping guanyu lijie xingshizhuyi guanliaozhuyi zhongyao lunshu xuanbian"” (Study "Selections of Xi Jinping's important essays on combating formalism and bureaucratism"), 3 June, http:/www.scio.gov.cn/31773/31774/31779/Document/ 1681597/1681597.htm. Accessed 9 September 2021.

Strauss, Julia C. 2019. State Formation in China and Taiwan: Bureaucracy, Campaign, and Performance. Cambridge: Cambridge University Press.

Terrill, Ross. 1999. Mao: A Biography. Stanford, CA: Stanford University Press.

Tian, Zhijian. 2020. "Dujue yiqing fangkong gongzuo zhong de xingshizhuyi, guanliaozhuyi" (Eliminate formalism and bureaucratism in epidemic prevention and control). Xinhuanet, 7 March, http://www. xinhuanet.com/politics/2020-03/07/c_1125677061.htm. Accessed 9 September 2021.

Vogel, Ezra. 1970. "Politicized bureaucracy: Communist China." In A. Doak Barnett and Fred W. Riggs (eds.), Frontiers of Development Administration. Durham, NC: Duke University Press, 556-568.

Wakeman, Frederic. 1975. "The use and abuse of ideology in the study of contemporary China." The China Quarterly 61, 127-152.

Walder, Andrew G. 2018. "Back to the future? Xi Jinping as an anti-bureaucratic crusader." China: An International Journal 16(3), 18-34.

Wang, Enxue. 2017. “Jiceng pibei: 'shijiu da' hou jixu zhongshi de wenti” (Grassroots fatigue: issues that needs urgent attention after the 19th Party Congress). Financial Times (Chinese), 8 December, https://www.ftchinese.com/story/001075391?archive. Accessed 9 September 2021.

Wang, Erik H. 2021. "Frightened Mandarins: the adverse effects of fighting corruption on local bureaucracy." Working paper, available at https://ssrn.com/abstract=3314508.

Wang, Peng, and Xia Yan. 2020. "Bureaucratic slack in China: the anti-corruption campaign and the decline of patronage networks in developing local economies." The China Quarterly 243, 611-634.

Wang, Yahua, and Quanfeng Shu. 2018. "Tuopin gongjian zhong de jiceng ganbu zhiye juandai: xianxiang, chengyin yu duice" (Burnout of grassroots cadres in the fight against poverty: phenomenon, causes, and countermeasures). Guojia xingzheng xueyuan xuebao 3, 130-158.

Whyte, Martin King. 1973. "Bureaucracy and modernization in China: the Maoist critique." American Sociological Review 38(2), 149-163.

Whyte, Martin King. 1989. "Who hates bureaucracy? A Chinese puzzle." In Victor Nee and David Stark (eds.), Remaking the Economic Institutions of Socialism: China and Eastern Europe. Stanford, CA: Stanford University Press, 233-254. 
Wong, Chun Han. 2021. "Xi Jinping's eager-to-please bureaucrats snarl his China plans." Wall Street Journal, 7 March, https://www.wsj.com/articles/xi-jinpings-eager-to-please-minions-snarl-his-chinaplans-11615141195. Accessed 9 September 2021.

Wu, Shufang. 2014. "The revival of Confucianism and the CCP's struggle for cultural leadership: a content analysis of the People's Daily, 2000-2009." Journal of Contemporary China 23(89), 971-991.

Yang, Dali L. 2004. Remaking the Chinese Leviathan: Market Transition and the Politics of Governance in China. Stanford, CA: Stanford University Press.

Zhou Enlai. 1963. "Fandui guanliaozhui" (Against bureaucratism), https://www.marxists.org/chinese/ zhouenlai/142.htm. Accessed 9 September 2021.

Zhou, Xueguang. 2017. Zhongguo guojia zhili de zhidu luoji: yige zuzhixue de yanjiu (The Institutional Logic of Governance in China: An Organizational Approach). Shanghai: Sanlian Press. 